\title{
Feeding ecology of Phalloceros anisophallos (Osteichthyes: Cyprinodontiformes) from Andorinha Stream, Ilha Grande, Brazil
}

\author{
Rosana Mazzoni ${ }^{1}$, Raphaella Rangel da Silva Araújo ${ }^{1}$, \\ Gardênia Carolina Tosta dos Santos ${ }^{1}$ and Ricardo Iglesias-Rios ${ }^{2}$
}

In the present work, we determined the relative importance of allochthonous and autochthonous food items as well as seasonal and ontogenetic variation in the feeding habits of Phalloceros anisophallos from córrego Andorinha, Ilha Grande. Quantitative analysis, based on alimentary index $\left(\mathrm{IA}_{\mathrm{i}}\right)$ and food volume $(\mathrm{Vo})$, revealed that $P$. anisophallos fed on detritus, autochthonous algae (diatoms, unicellular and filamentous Chlorophyceae algae), autochthonous animals (aquatic insect larvae: Trichoptera, Chironomidae and other Diptera) and allochthonous animals (terrestrial insects: Hymenoptera). Ontogenetic variations were recorded for the consumption of each food category. Adults used a larger amount of algae and detritus, and juveniles used a higher amount of animal items. Significant differences in intestinal coefficient between adult and juvenile individuals corroborated the ontogenetic differences in feeding behavior. $\mathrm{IA}_{\mathrm{i}}$ values of each consumed food category did not vary between the rainy and dry seasons, but mean detritus Vo differed between seasons and was significantly (Anova, $p<0.01$ ) greater during the dry season.

No presente trabalho determinamos a importância relativa dos itens de origem alóctone e autóctone, bem como as variações sazonais e ontogenéticas do hábito alimentar de Phalloceros anisophallos do córrego Andorinha, Ilha Grande. Análises quantitativas baseadas no índice alimentar ( $\mathrm{IA}_{\mathrm{i}}$ ) e no volume (Vo) de cada item alimentar revelaram que P. anisophallos se alimentou de detrito, algas (diatomáceas, unicelulares e clorofíceas filamentosas), animais autóctones (larvas de insetos aquáticos: Trichoptera, Chironomidae e outros Diptera) e animais alóctones (insetos terrestres: Hymenoptera). Foram registradas variações ontogenéticas para o consumo de cada categoria alimentar. Os adultos consumiram maiores quantidades de algas e detrito enquanto os jovens consumiram maiores quantidades de itens animais. As diferenças significativas do coeficiente intestinal de adultos e jovens corroboraram as diferenças ontogenéticas do hábito alimentar. Os valores de IA de cada categoria alimentar consumida não variou entre as estações chuvosa e seca, mas os valores médios do volume de detrito consumido variou entre as estações e foi significativamente (Anova, $\mathrm{p}<0.01$ ) superior na estação seca.

Key words: Poeciliidae, Atlantic Rain Forest, Coastal stream, Ontogeny, Seasonality.

\section{Introduction}

In upstream areas, with high canopy density, trees shade the water surface and reduce primary production, and food webs are dependent on allochthonous matter. In such cases, fish feed mainly on allochthonous matter such as terrestrial insects and seeds (Welcomme, 1985; Luiz et al., 1998). These conditions are found in Mata Atlântica streams, where rivers normally drain closed-canopy forests and where allochthonous production seems to support aquatic life (Moulton \& Magalhães, 2003).

Fish feeding habits vary in a cyclic manner according to seasonal rhythms of physical variables, such as rainfall, photoperiod and temperature (Zavala-Camin, 1996), and biological variables, such as competition and vegetation. Nonetheless, in tropical areas, rainfall and vegetation are among the main variables affecting biological traits of fish species (Munro, 1990; Wootton, 1990). Considering the large number of Mata Atlântica streams draining the Brazilian coast and their importance for conservation priorities as sources of endemic species (Mazzoni et al., 2000; Mazzoni et al., 2009), information concerning the feeding biology of this fish fauna is important but very scarce (Sabino \& Castro, 1990; Castro \& Casatti, 1997; Aranha \& Caramaschi, 1999; Mazzoni \& Iglesias-Rios, 2002; Mazzoni \& Rezende, 2003).

Phalloceros Eigenmann, 1907 comprises small poeciliin fishes broadly distributed throughout the southern rivers of South America (Lucinda, 2003), one of the eight areas of endemism for poeciliines on the American continent (Lucinda $\&$ Reis, 2005). The Phalloceros species have been hardly studied with regard to ecology, anatomy, embryology, and many others biological aspects; nonetheless, from the perspective of systematics, it has been poorly studied since Lucinda (2008) revised the genus and identified twenty-one new species, previously classified as Phalloceros caudimaculatus. Phalloceros anisophallos Lucinda 2008 is

${ }^{1}$ Universidade do Estado do Rio de Janeiro, Instituto de Biologia Roberto Alcântara Gomes, Departamento de Ecologia. Rua São Francisco Xavier 524, Maracanã, 20550-013 Rio de Janeiro, RJ, Brazil. mazzoni@uerj.br

${ }^{2}$ Universidade Federal do Rio de Janeiro, Instituto de Biologia, Departamento de Ecologia. CP 68020, Rio de Janeiro, RJ, Brazil. rir@biologia.ufrj.br 
one of these species and was described with material collected from the drainages of rio Parati, rio Barra Grande (= córrego Andorinha - Ilha Grande), rio São Roque, rio Taquari and rio Itinguçu, all of them from the small coastal drainages of the state of Rio de Janeiro.

In the present work, we analyzed the relative importance of allochthonous and autochthonous material as well as seasonal and ontogenetic variation on the feeding habits of Phalloceros anisophallos from córrego Andorinha, Ilha Grande, a tropical rain forest island from Mata Atlântica.

\section{Material and Methods}

Ilha Grande $\left(23^{\circ} 05^{\prime}-23^{\circ} 15^{\prime} \mathrm{S}\right.$ and $\left.44^{\circ} 06^{\prime}-44^{\circ} 23^{\prime} \mathrm{W}\right)$ is one of the biggest islands along the Rio de Janeiro coast, where its Atlantic Rainforest shows different levels of regeneration following century-old anthropogenic disturbances. Some remnants of primary forest can still be found in the most inaccessible areas (Bittencourt \& Rocha, 2002), mainly at headwaters. It is characterized by marked rainy and dry seasons with annual precipitation of about $2200 \mathrm{~mm}$ (Estação Meteorológica da Central Nuclear de Angra dos Reis NUCLEN) and maximum and minimum water temperature of $25.7^{\circ} \mathrm{C}$ in February and $19.6^{\circ} \mathrm{C}$ in July (Oliveira \& Neto, 1996).

Several streams drain both the eastern and western slopes of Ilha Grande and, because of their high inclination, as well as their geological landscape, these streams are very poor in freshwater fish diversity and densities (Rezende \& Mazzoni, 2006). Among the most abundant species, Phalloceros anisophallos has the widest distribution along the córrego Andorinha.

The study area comprised a stretch of about $80 \mathrm{~m}$ long in córrego Andorinha, at approximately $100 \mathrm{~m}$ asl (above sea level). It has a poor marginal vegetation and abundant canopy $(\sim 90 \%)$. Stream flow is fast, the stretch shows prevailing riffles and runs with rocky and gravel substrata as well as pools with accumulated sand and debris.

Samples were taken monthly between November 1999 and October 2000 using only hand nets and sieves with mesh size from 0.2 to $0.5 \mathrm{~cm}$. At each sampling occasion, between 15 and 20 specimens of $P$. anisophallos were collected. Specimens were kept in ice for transportation and processed in the laboratory, and the following data were obtained: (i) standard length $\left(\mathrm{L}_{\mathrm{s}}\right.$, $\mathrm{cm}$ ), (ii) total weight ( $\left.\mathrm{W}_{\mathrm{T}}, \mathrm{gr}\right)$, (iii) stomach weight $\left(\mathrm{W}_{\mathrm{S}}, \mathrm{mg} \mathrm{x} 10\right.$ ) and (iv) intestine length $\left(\mathrm{L}_{\mathrm{r}}, \mathrm{cm}\right)$. Stomachs were fixed for three days in $5 \%$ formalin and then stored in $70^{\circ} \mathrm{GL}$ alcohol.

Stomach contents were examined under stereoscopic and light microscopes according to the frequency of occurrence (Fo) and volumetric (Vo) methods (Hyslop, 1980). Food items were identified according to the corresponding literature (Chu, 1949; Bicudo \& Bicudo, 1970; Merritt \& Cummins, 1984). Depending on the analysis, objective food items were classified according to: (1) three food categories - (i) animal = aquatic or terrestrial insects - adult and larvae, (ii) plant/algae $=$ seeds, leaves, algae and (iii) detritus $=$ decomposing material or (2) food item origin - (i) allochthonous and (ii) autochthonous. The volume of each food category/origin was estimated using a Sedgewick-Rafter counting camera (SRcc).

The relative importance of each food item category was established according to the alimentary index $\left(\mathrm{IA}_{\mathrm{i}}\right)$. IA consisted of the correlation between Fo and Vo data as proposed by Kawakami \& Vazzoler (1980) and adapted by Hahn et al. (1997) and was applied according to the following model: $\mathrm{IA}_{\mathrm{i}}=\left(\mathrm{F}_{\mathrm{i}}^{*} \mathrm{~V}_{\mathrm{i}}\right) /\left(\Sigma \mathrm{F}_{\mathrm{i}}{ }^{*} \mathrm{~V}_{\mathrm{i}}\right){ }^{*} 100$, where $\mathrm{i}=1,2, \ldots$. n food items; $F_{i}=$ frequency of occurrence and $\mathrm{Vo}=$ volume of a given food item; $\mathrm{IA}_{\mathrm{i}}$ values varied as follows: $0 \leq \mathrm{IA}_{\mathrm{i}} \leq 100$.

Intestinal coefficient $\left(\mathrm{I}_{\mathrm{C}}\right)$ was estimated according to: $\mathrm{I}_{\mathrm{C}}=$ $\mathrm{L}_{\mathrm{I}} / \mathrm{L}_{\mathrm{S}}$, where $\mathrm{L}_{\mathrm{I}}=$ intestine length and $\mathrm{L}_{\mathrm{S}}=$ standard length (Barbieri et al., 1994), and was applied as complementary information for feeding habit classification and its ontogenetic variation. Ontogenetic variations of feeding habits were based on the $\mathrm{IA}_{\mathrm{i}}$ and Vo values of each food category (detritus, animal and plant/algae) of adult and juvenile specimens. Ontogenetic variations in $\mathrm{I}_{C}$ were based on mean $\mathrm{I}_{C}$ values of juvenile and adult fish. Specimens were classified as juveniles or adults according to data for $1^{\text {st }}$ maturation $\left(\mathrm{L}_{\mathrm{S} 50}=2.0 \mathrm{~cm}\right)$, and thus, adults were those individuals with $\mathrm{L}_{\mathrm{s}} \geq 2.0 \mathrm{~cm}$ and juveniles were individuals with $\mathrm{L}_{\mathrm{S}}<2.0 \mathrm{~cm}$. Seasonal (rainy and dry seasons) variation in feeding habits was determined according to Vo and the relative importance $\left(\mathrm{IA}_{\mathrm{i}}\right)$ of allochthonous and autochthonous items.

Differences in consumption based on mean Vo of detritus, plant/algal and animal food items eaten by juveniles and adults and the seasonal (rainy vs. dry) variations in mean Vo of detritus, autochthonous plant/algae and animal and allochthonous animal were tested by Anova $(\alpha=0.01)$. The $\mathrm{I}_{\mathrm{C}}$ values were submitted to a t-test to verify differences between juveniles and adults. All statistical tests were carried out using STATISTICA 7.0 software (StatSoft, 1996).

\section{Results}

One hundred and seven individuals were analyzed, including 46 juveniles and 61 adults, where 51 were from the dry season and 56 from the rainy season. Voucher specimens were placed in the fish collection of Museu Nacional do Rio de Janeiro (MNRJ 28725) and Universidade Federal do Tocantins (UNT 6772 - paratype specimen).

Considering the whole sample, of both juvenile and adult individuals, quantitative analyses indicated that $P$. anisophallos fed on detritus, autochthonous algae (diatoms and unicellular and filamentous Chlorophyceae algae), autochthonous animals (aquatic insect larvae: Trichoptera, Chironomidae and other Diptera) and allochthonous animals (terrestrial insects: Hymenoptera). Detritus was the most important item $\left(\mathrm{IA}_{\mathrm{i}}=57.79\right)$, followed by autochthonous algae $\left(\mathrm{IA}_{\mathrm{i}}=32.11\right)$. Mean $\mathrm{I}_{\mathrm{C}}$ was $3.8( \pm 1.8)$.

Juvenile and adult specimens differed in the use of detritus, algae and animal items. Adults used a greater amount of algal items and detritus $\left(\Sigma \mathrm{IA}_{\mathrm{i}}=92\right)$, but juveniles used a greater amount of animal items (IAi $=83$ ) (Fig. 1). Significant differences in Vo for each food category were recorded (Anova; $\mathrm{F}_{\text {adults }}=38.2 ; \mathrm{F}_{\text {juveniles }}=4.2 ; \mathrm{p}<0.01$ ), which corroborated the above mentioned $\mathrm{IA}_{\mathrm{i}}$ results (Figs. 1). 


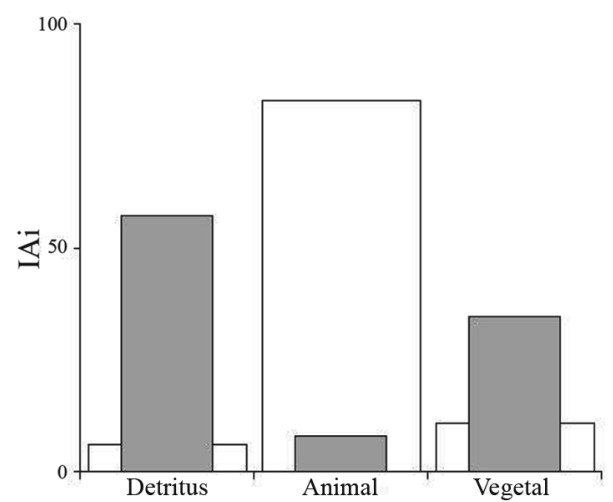

Fig. 1. Comparison between juvenile (white) and adult (grey) alimentary index (IA $)$ of each food category consumed by Phalloceros anisophallos from córrego Andorinha (Ilha Grande, Rio de Janeiro).

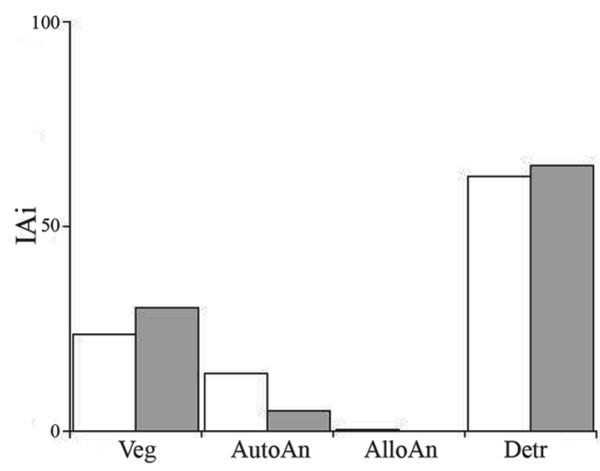

Fig. 2. Comparison of alimentary index $\left(\mathrm{IA}_{\mathrm{i}}\right)$ of each food category consumed by Phalloceros anisophallos from córrego Andorinha (Ilha Grande, Rio de Janeiro) during the rainy (white bars) and dry (grey bars) seasons. Alg = autochthonous algae, AutoAn = autochthonous animal, AlloAn $=$ allochthonous animal and Detr $=$ detritus .

Intestinal coefficient $\left(\mathrm{I}_{\mathrm{C}}\right)$ differed significantly between $L_{\mathrm{S}}$ groups ( $\mathrm{t}$-test $\mathrm{t}=5.33 ; \mathrm{p}<0.01$ ); mean values were $4.9 \pm 1.7$ and $2.9 \pm 1.2$ for adult and juvenile individuals, respectively.

The relative importance (IA - Fig. 2) of each food category consumed by $P$. anisophallos did not vary between the rainy and dry seasons. Temporal variation of mean volume of autochthonous algae, allochthonous animal and detritus was tested by ANOVA; a post hoc test (Tukey) showed significant differences $\left(\mathrm{F}_{\text {juveniles }}=5.6 ; \mathrm{p}<0.01\right)$ only for the detritus consumption, where the dry season showed the higher incidence of this food category.

\section{Discussion}

Phalloceros anisophallos from córrego Andorinha displayed an omnivorous diet based mainly on autochthonous resources from the sediment (insect larvae, algae and detritus). Small participation of allochthonous items (terrestrial insects) was also recorded. Mean value of intestinal coefficient $\left(\mathrm{I}_{\mathrm{C}}\right)$ was 3.8, corroborating the omnivorous classification and was in agreement with the $\mathrm{I}_{\mathrm{C}}$ range proposed by Barbieri et al. (1994).
We found differences in feeding habits and $\mathrm{I}_{\mathrm{C}}$ range related to ontogenetic development. Juvenile specimens (size greater than that of $1^{\text {st }}$ maturation) showed high occurrence of aquatic insects and larvae and lower $\mathrm{I}_{\mathrm{C}}$ values, whereas adults showed higher occurrence of algae and $\mathrm{I}_{\mathrm{C}}$ values. Based on these differences and according to Barbieri et al. (1994), we classified adult and juvenile specimens as detritivorous/algivorous and insectivorous, respectively.

A number of studies concerning Poeciliidae feeding habits have pointed out that algae and periphyton appear to be the main food resource among these species, where little or no ingestion of animal items have been recorded (e.g., Costa, 1987; Aranha \& Caramaschi, 1999). Costa (1987) reported that $100 \%$ of the diet of a stream-dwelling population of $P$. caudimaculatus was based on algae, and Teixeira (1989) found only large amounts of plant/algal items in stomach content of another population from a coastal stream in Rio Grande do Sul. Nonetheless, Aranha \& Caramaschi (1999), studying a population of $P$. caudimaculatus from a coastal stream in Rio de Janeiro, reported that animals (larvae and insects) were found in $99 \%$ of the stomachs analyzed. Nonetheless, Sabino \& Castro (1990) classified P. caudimaculatus as omnivorous tending toward herbivorous. We must be aware, however, that the several populations then called $P$. caudimaculatus were latter split in twenty two species by Lucinda (2008).

The results presented in this study provide strong evidence that animal items as well as detritus are important food resources for $P$. anisophallos from córrego Andorinha. Given the structural landscape of the study site, where a closed canopy is the main local characteristic, we suppose that the absence of sunlight which facilitates primary production is the main reason for the low incidence of plant/algal items in the species' diet.

It has been repeatedly mentioned that animal items such as aquatic larvae and aquatic and/or terrestrial insects, both of autochthonous and/or allochthonous origin, are important elements in stream food webs and are an important food source for stream-dwelling fishes (Lowe-McConnell, 1987), but strong differences in the nature of feeding habits of the same species living under different environmental conditions have also been reported (Esteves \& Aranha, 1999).

In fact, very different results were found in the literature concerning the feeding habits of Phalloceros species from Mata Atlântica streams in southern Brazil. In many cases, species were classified as omnivorous (e.g., Sabino \& Castro, 1990; Castro \& Casatti, 1997; Deus \& Petrere-Junior, 2003), whereas in others they were classified as herbivorous (e.g., Costa, 1987; Teixeira, 1989; Casatti, 2002). This feeding flexibility could be attributed to the use of different feeding tactics, such as picking items off the surface, backbiting and capturing food near the bottom (Sazima, 1986).

In the present work, we found that the importance of autochthonous items superimposed that of the allochthonous ones. We were unable to find clear evidence of seasonal changes in food consumption, probably due to the constant availability of food and also because of the large feeding spectrum shown by the species studied. The ontogenetic variation in feeding habits of Phalloceros anisophallos from córrego Andorinha 
should be one of the explanations for these results by reducing the consumption of only one kind of food category.

\section{Acknowledgements}

We thank the members of the Laboratório de Ecologia de Peixes of the Universidade do Estado do Rio de Janeiro for helping in the field work, and Chiara Mazzoni for English revision. This study is part of a Scientific Initiation work (PIBIC/ UERJ) by GCT and RRSA and was partially supported by FAPERJ-APQ1 -E-26/171555/2000 and CEADS / SR2 / UERJ.

\section{Literature Cited}

Aranha, J. M. R. \& E. P. Caramaschi. 1999. Estrutura populacional, aspectos da reprodução e alimentação dos Cyprinodontiformes (Osteichthyes) de um riacho do sudeste do Brasil. Revista Brasileira de Zoologia, 16(1): 637-651.

Barbieri, G., A. C. Peret \& J. R. Verani. 1994. Notas sobre a adaptação do trato digestivo ao regime alimentar em espécies de peixes da região de São Carlos (SP). I. Quociente Intestinal. Revista Brasileira de Biologia, 54(1): 63-69.

Bicudo, C. E. M. \& R. M. Bicudo. 1970. Algas de águas continentais brasileiras. São Paulo, FUNBEC, 228p.

Bittencourt, E. B. \& C. F. D. Rocha. 2002. Spatial use of rodents (Rodentia: Mammalia) host body surface by ectoparasites. Brazilian Journal of Biology, 62(3): 419-425.

Casatti, L. 2002. Alimentação dos peixes em um riacho do Parque Estadual Morro do Diabo, bacia do Alto Paraná, sudeste do Brasil. Biota Neotropica, 2 (2): 01-14.

Castro, R. M. C. \& L. Casatti. 1997. The fish fauna from a small forest stream of the upper Paraná River basin, Southeastern Brazil. Ichthyological Explorations of Freshwaters, 7(4): 337-352.

Chu, H. F. 1949. The immature insects. Iowa, Brown Company Publishers, 234p.

Costa, W. J. E. M. 1987. Feeding habits of a fish community in a tropical coastal stream, Rio Mato Grosso, Brazil. Studies on Neotropical Fauna and Environment, 22(3): 145-153.

Deus, C. P. \& M. Petrere-Júnior. 2003. Seasonal diet shifts of seven fish species in an Atlantic rainforest stream in southeastern Brazil. Brazilian Journal of Biology, 63(4): 579-588.

Esteves, K. E. \& J. M. R. Aranha. 1999. Ecologia trófica de peixes de riacho. Pp. 157-182. In: Caramaschi, E. P., R. Mazzoni \& P. R. Peres-Neto (Eds.). Ecologia de peixes de riacho. Série Oecologia Brasiliensis, vol. VI. PPGE/UFRJ/Rio de Janeiro, Computer \& Publish editoração Ltda.

Hahn, N. S., V. L. L. Almeida \& K. D. G. Luz. 1997. Alimentação e ciclo alimentar diário de Hoplosternum littorale (Hancock) (Siluriformes, Callichthyidae) nas lagoas Guaraná e Patos da Planície do Alto Paraná, Brasil. Revista Brasileira de Zoologia, 14(1):57-64.

Hyslop, E. J. 1980. Stomach contents analysis - a review of methods and their application. Journal of Fish Biology, 17: 411-429.

Kawakami, E. \& G. Vazzoler. 1980. Método gráfico e estimativa de índice alimentar aplicado no estudo da alimentação de peixes. Boletim do Instituto Oceonográfico, 29: 205-207.

Lowe-McConnell, R. M. 1987. Ecological studies in tropical fish communities. Cambridge University Press, 381p.

Lucinda, P. H. F. 2003. Family Poeciliidae. Pp. 555-581. In: Reis, R. E., S. O. Kullander \& C. J. Ferraris Jr. (Eds.). Check list of the freshwater fishes of South and Central America. Porto Alegre, Edipucrs, 729p.

Lucinda, P. H. F. 2008. Systematics and biogeography of the genus Phalloceros Eigenmann, 1907 (Cyprinodontiformes: Poeciliidae:
Poeciliinae), with the description of twenty-one new species. Neotropical Ichthyology, 6(2): 113-158.

Lucinda, P. H. F. \& R. E. Reis. 2005. Systematics of the subfamily Poeciliinae Bonaparte (Cyprinodontiformes, Poeciliidae). Neotropical Ichthyology, 3(1): 1-60.

Luiz, E. A., A. A. Agostinho, L. C. Gomes \& N. S. Hahn. 1998. Ecologia trófica de peixes em dois riachos da bacia do rio Paraná. Revista Brasileira de Biologia, 58: 273-285.

Mazzoni, R., C. R. F. Bizerril, P. A. Buckup, O. Caetano, C. A. Figueiredo, N. A. Menezes, G. Nunam \& K. Tanizaky. 2000. Peixes. Pp. 63-73. In: Bergallo, H. G., C. F. D. Rocha, M. Van Sluys \& M. A. S. Alves (Orgs.). A Fauna Ameaçada de Extinção do Rio de Janeiro. Rio de Janeiro, Ed. UERJ, 220p.

Mazzoni, R., C. A. Figueiredo, M. C. Enrici, E. P. Caramaschi, J. L. Nessimian \& T. P. Moulton. 2009. Organismos aquáticos nos sistemas fluviais do Estado do Rio de Janeiro. Pp. 153-174. In: Bergallo, H. G., E. C. C. Fidalgo, C. F. D. Rocha, M. C Uzêda, M. B. Costa, M. A. S. Alves, M. Van Sluys, M. A. Santos, T. C. C. Costa, A. C. R. Cozzolino (Orgs.). Estratégias e Ações para a Conservação da Biodiversidade do Estado do Rio de Janeiro. Rio de Janeiro, 344p.

Mazzoni. R. \& R. Iglesias-Rios. 2002. Distribution pattern of two fish species in a coastal stream in the southeast of Brazil. Brazilian Journal of Biology, 62(1): 171-178.

Mazzoni, R. \& C. F. Rezende. 2003. Seasonal diet shift in a Tetragonopterinae (Osteichthyes, Characidae) from the Ubatiba River, RJ - Brazil. Brazilian Journal of Biology, 63(1): 69-74.

Merrit, R. W. \& K. W. Cummins. 1984. An introduction to the Aquatic Insets of North America. Duboque, Kendall \& Hunt Publishing Company, 722p.

Moulton, T. P. \& S. A. P. Magalhães. 2003. Responses of leaf processing to impacts in streams in Atlantic Rain Forest, Rio de Janeiro, Brazil - A test of the biodiversity-ecosystem function relationship? Brazilian Journal Biology, 63: 87-95.

Munro, A. D. 1990. General Introduction. Pp. 1-12. In: Munro, A. D., A. P. Scott \& T. J. Lam (Eds.). Reproductive Seasonality in Teleosts: Environmental Influences. Boca Raton, Florida CRC Press Inc, 254p.

Oliveira, R. R. \& A. L. C. Neto. 1996. Os rastros do homem na floresta. Albertoa, 4: 109-116.

Rezende, C. F. \& R. Mazzoni. 2006. Contribuição da matéria autóctone e alóctone para a dieta de Bryconamericus microcephalus (Miranda-Ribeiro) (Actinopterygii, Characidae), em dois trechos de um riacho de Mata Atlântica, Rio de Janeiro, Brasil. Revista Brasileira de Zoologia, 23(1): 58-63.

Sabino, J. \& R. M. C. Castro. 1990. Alimentação, período de atividade e distribuição espacial dos peixes de um riacho da floresta Atlântica (Sudeste do Brasil). Revista Brasileira de Biologia, 50(1): 23-36.

Sazima, I. 1986. Similarities in feeding behaviour between some marine and freshwater fishes in two tropical communities. Journal Fish Biology, 29 (1): 53-65.

Teixeira, R. L. 1989. Aspectos da ecologia de alguns peixes do arroio Bom Jardim, Triunfo-RS. Revista Brasileira de Biologia, 49(1): 183-192.

Welcomme, R. L. 1985. Ontogenetic diet shifts and resource partitioning among piscivorous fishes in the Venezuelan llanos. Environmental Biology of Fish, 26: 177-199.

Wootton, R. J. 1990. Ecology of teleost fishes: fish and fisheries. London, Chapman \& Hall, 404p.

Zar, J. H. 1996. Biostatistical analysis. Englewood Cliffs. New Jersey, Prentice-Hall, 662p.

Zavala-Camin, L. A. 1996. Introdução ao estudo sobre alimentação natural em peixes. Maringá, EDUM, 129p.

Accepted January 5, 2010

Published March 31, 2010 